\title{
Unit Labour Costs and the Dynamics of Output and Unemployment in the Southern European Crisis Countries
}

\author{
Juan Carlos Cuestas ${ }^{\dagger}$ \\ Department of Economics, Jaume I University \\ Research Unit, Economics and Research Department, Eesti Pank \\ Department of Economics and Finance, Tallinn University of Technology \\ Javier Ordóñez \\ Department of Economics, Jaume I University \\ Karsten Staehr \\ Department of Economics and Finance, Tallinn University of Technology \\ Research Unit, Economics and Research Department, Eesti Pank
}

\begin{abstract}
The GIPS countries, the southern European crisis countries, have seen depressed output dynamics and high unemployment rates during the great recession following the 2007-2008 financial crisis. This paper considers the effects of measures that seek to improve competitiveness by reducing real unit labour costs. The results are derived in structural vector autoregressive models for each of the GIPS counties as well as two reference countries, Germany and the Netherlands. The responses of output and unemployment to innovations in real unit labour costs are economically and statistically significant for Germany and the Netherlands, whereas the responses are typically muted and imprecise estimated for the GIPS countries. The small and uncertain effects raise doubts regarding the efficacy of measures that seek to lower real unit labour costs in the GIPS countries.
\end{abstract}

Key words: internal devaluation, economic crisis, GIPS, SVAR, Bayesian econometrics.

JEL codes: C11, C33, E23, E52, E62

\footnotetext{
* The views expressed are those of the authors and do not necessarily represent the official views of Eesti Pank or other parts of the Eurosystem. Comments from two referees are gratefully acknowledged. The authors acknowledge support from the Generalitat Valenciana project grant no. AICO/2016/038. Juan Carlos Cuestas and Javier Ordonez also acknowledge support from the project ECO2017-83255-C3-3-P, 'Programa Estatal de Fomento de la Investigación, Científica y Técnica de Excelencia, Subprograma Estatal de Generación de Conocimiento, Ministerio de Economía, Industria y Competitividad (MINEIC), Gobierno de España, 20182020 '.

${ }^{\dagger}$ Corresponding author, email: cuestasjuancarlos@gmail.com.
} 


\section{Introduction}

Could measures to improve cost competitiveness be used as a means for pulling European countries out of the slowdown that has followed the global financial crisis? This paper estimates quarterly SVAR models and uses them to compute impulse responses showing how movements in real unit labour costs affect output and unemployment. The analyses focus on Greece, Italy, Portugal and Spain, collectively the GIPS countries, which are the southern European countries that were severely affected by the great recession following the global financial crisis. To facilitate the interpretation of the results, Germany and the Netherlands are included as reference countries.

Several southern European countries experienced a period of high rates of economic growth and declining unemployment from the mid-1990s as the introduction of the euro moved closer and eventually became a reality. The countries saw unit labour costs rise while economic and financial imbalances accumulated. The outbreak of the global financial crisis affected the countries severely and they have in the following decade seen depressed output performance and persistently high unemployment rates. The economic and social costs are evident and may threaten societal cohesion in those countries.

These developments have led to fervent debates about the importance of competitiveness for macroeconomic performance (Hall, 2012). We may distinguish two strands in the literature. One consists of papers that find competitiveness to have affected growth. Ordóñez et al. (2015) conclude that the economic crisis was caused by differences in competitiveness which generated real divergences and growing current account imbalances. Consistent with this view, Caporale and Gil-Alana (2014) find evidence that misalignment of the real exchange rate affects longer-term growth. Staehr and Vermeulen (forthcoming) use different measures of competitiveness and find that deteriorating competitiveness affects output negatively in many countries in the euro area, though there is substantial heterogeneity across the countries.

Sinn (2014) posits that the euro itself was partly responsible for the lack of competitiveness in the southern European countries. Creating a common currency reduced risk premiums in the peripheral countries, and this led to greater spending on both consumption and investment, which was fuelled by an abundance of cheap credit that drove an inflationary boom, particularly in housing, which made those countries uncompetitive. To make matters worse, 
the euro area did not have adequate mechanisms for managing these risks, and the peripheral countries also failed to take adequate precautionary measures (Guerrieri and Esposito, 2012).

Zemanek (2010) and Sinn (2014) discuss the divergent developments within the euro area and conclude that downward adjustment of labour costs may be the key to strengthening macroeconomic performance and pulling the affected countries out of the crisis.

The other strand of the literature generally argues that competitiveness problems are largely a symptom of other issues. Schmitt-Grohé and Uribe (2016) show that the combination of perfect capital mobility and downward wage rigidity can lead to excessive external borrowing during booms and subsequently to high unemployment during recessions. Wyplosz (2013) and Gros (2016) provide policy discussions about the imbalances within the euro area and conclude that competitiveness is not at the core of the problems. Gabrisch and Staehr (2015) find that deteriorating competitiveness may stem from large capital inflows. They find evidence of Granger causality from international capital flows to real unit labour costs in panels of EU countries, but not in the opposite direction.

Cirillo and Guarascio (2015) note that the disappointing developments in the labour markets of the GIPS countries during the great recession stem in part from changes in external demand. The southern European countries have traditionally concentrated on light manufacturing and such products are subject to intense competitive pressures that suggest the structure of production needs to change. Along the same lines, Storm and Naastepad (2015) argue that the strong performance of Germany does not stem from depressed wage rates but rather from the significant non-price competitiveness that German exports exhibit.

While the academic debate has rumbled in the background, competitiveness has been on the forefront of economic policy-making in the European Union and in individual countries. The EU has introduced several measures that target competitiveness, including the Euro Plus Pact and the Macroeconomic Imbalance Procedure (MIP) of the Six Pack. The MIP Scoreboard stipulates that rises in nominal unit labour costs over three years cannot exceed nine per cent for euro area countries and 12 per cent for other EU countries (EC, 2017). In the policymaking framework, the progress that followed the labour market reforms in Germany in the early 2000s has frequently been cited as evidence that wage moderation may boost production and reduce unemployment (Hall, 2012; Dustmann and Fitzenberger, 2014).

Labour markets have been reformed to enforce wage moderation and restore competitiveness in the peripheral countries. However, there are concerns that reducing unit labour costs 
through negative wage adjustments may be counter-productive. Stockhammer and Sotiropoulos (2014) take a Keynesian view and argue that downward wage flexibility may not be effective in reducing the effects of adverse shocks. Cuts in wages may reduce consumption, lower aggregate demand and eventually raise unemployment, giving rise to a debt-deflation Fisher effect. This outcome may be particularly relevant for many southern European countries. Blanchard and Portugal (2017) note that high-debt countries that seek to improve their competitiveness may require deflation to do so, but deflation raises the real value of the debt and hence restrains internal demand. Storm and Naastepad (2014) similarly argue that wage reductions in the crisis countries may suppress demand, but they attribute the effect to negative effects on consumption and investment confidence. Galí and Monacelli (2016) show that wage adjustment is much less effective in a currency union such as the euro area than in countries with a floating exchange rate. Felipe and Kumar (2014) stress that unit labour costs are of importance for the income distribution and hence demand, and a decline in unit labour costs would therefore possibly cause a deeper recession in the southern European crisis countries.

The discussion above underscores the extensive debate about how wage policies and other measures could be used to improve cost competitiveness in order to combat economic imbalances and high unemployment rates in the EU, especially in the GIPS countries. The linkages between real unit labour costs and unemployment are conceptually complex. Changes in real unit labour costs may feed into output and labour markets through numerous channels depending on the institutions and specific conditions of the economy. This suggests that detailed empirical analyses are needed but also that such analyses must be made for individual countries to take account of possible heterogeneity (Staehr and Vermeulen, forthcoming). ${ }^{1}$

There are only few detailed empirical analyses that seek to ascertain how cost competitiveness affects the dynamics of output and unemployment in individual EU countries. This paper addresses this research gap by evaluating the effects of real unit labour costs using impulse response functions from structural vector autoregressive (SVAR) models. The SVAR models are estimated on quarterly data and specified with four macroeconomic variables: real unit labour costs, the current account balance, output, and the unemployment rate.

\footnotetext{
${ }^{1}$ Blanchard and Wolfers (2000) show that the oil price shocks in the 1970s affected different OECD economies very differently, depending on their institutional features.
} 
The analyses focus on the four GIPS countries which were among the countries most severely affected by the global financial crisis and the great recession that followed. Greece and Portugal are relatively small economies, while Italy and Spain are the third and fourth largest euro area countries. To facilitate the interpretation of the results, we include two reference countries from the core of the euro area. Germany is the largest euro area country and an obvious choice given its key position in the euro area. However, given the size of the Greek and Portuguese economies, we also include the Netherlands as reference country since the global financial crisis and the following great recession may have affected small and open economies disproportionately.

We obtain results for each of the four GIPS countries and the two core countries for two time periods, with one set of results from the longest available sample, which runs from 1995Q1 to 2016Q4 in most cases, and one set from the sample after 2007Q1. The SVAR models for the full sample are estimated using traditional frequentist econometrics. The SVAR models for the period after 2007Q1 are estimated using Bayesian econometrics and the impulse responses are meant to show the effects of innovations in unit labour costs when data for the post-crisis sample are used.

The results from the SAR models reveal that changes in real unit labour costs only have clear and statistically significant effects on GDP and the unemployment rate in Germany and the Netherlands, while the effects for the GIPS countries typically are small and not statistically significant. These results hold whether the SVAR models are estimated using data from the full sample period or from the shorter post-crisis period.

The remainder of the paper is organised as follows. In the next section, we present the series of unemployment rates and real unit labour costs along with brief descriptions of key structural reforms affecting these variables. In Section 3 we present a description of the data sources and variables and a summary of the econometric methods used, particularly for the shorter period. In Section 4 we present the results of the analysis and discuss them. In the last section we conclude the paper.

\section{The evolution of real unit labour costs and unemployment}

In this section we show how real unit labour costs and unemployment rates evolved from the first quarter 1995 to the fourth quarter 2016 in the six countries considered. Some key reforms 
which may have affected the developments of the two variables are also discussed. Figure 1 shows quarterly data on the real unit labour costs and the unemployment rate, both seasonally adjusted, for the period 1995Q1-2016Q4. ${ }^{2}$ The plots are for the four southern European crisis countries and also for the two reference countries, Germany and the Netherlands. ${ }^{3}$

\footnotetext{
${ }^{2}$ The unit labour costs are computed as labour compensation per employee divided by the gross domestic product per person employed.

${ }^{3}$ More information on the data series is provided in Section 3.
} 
Figure 1: Real unit labour costs and unemployment rates, seasonally adjusted

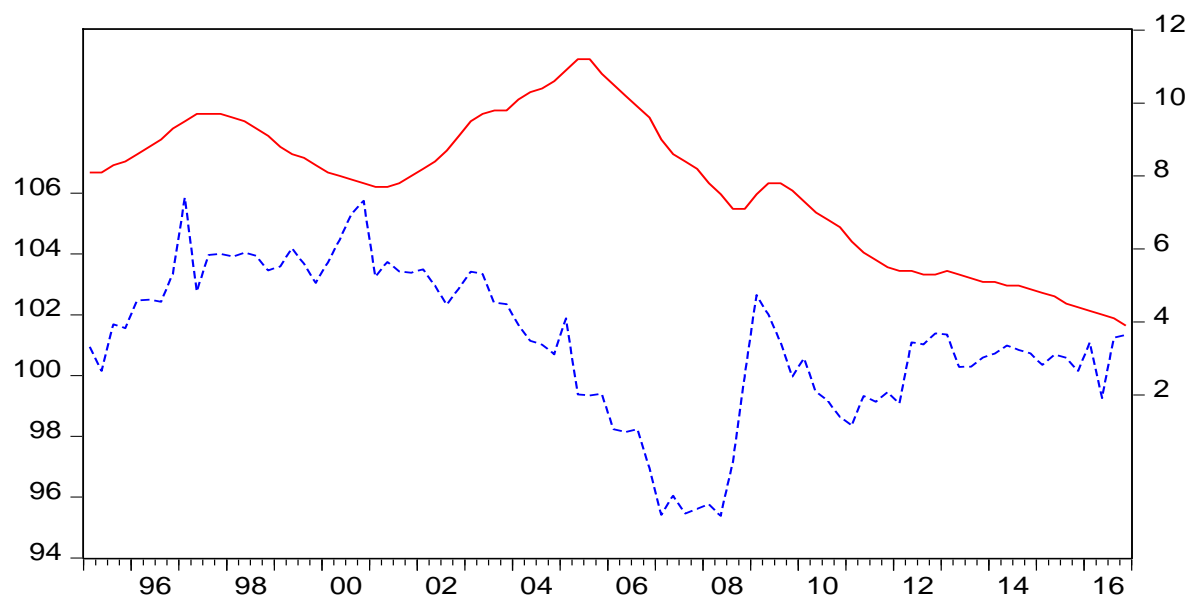

(a) Germany

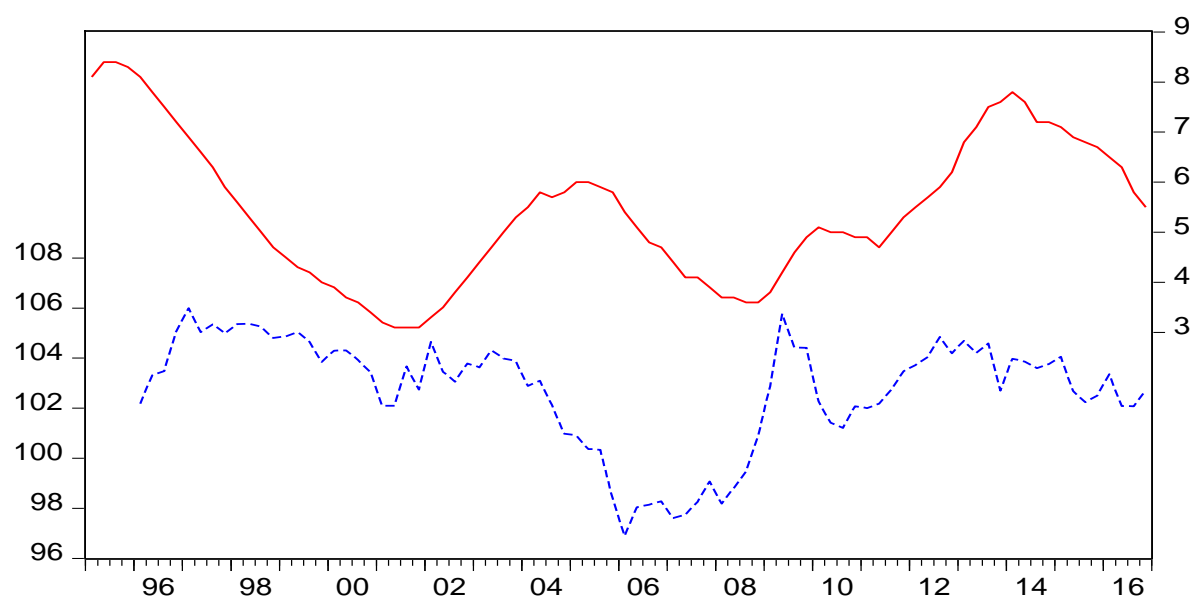

(b) Netherlands

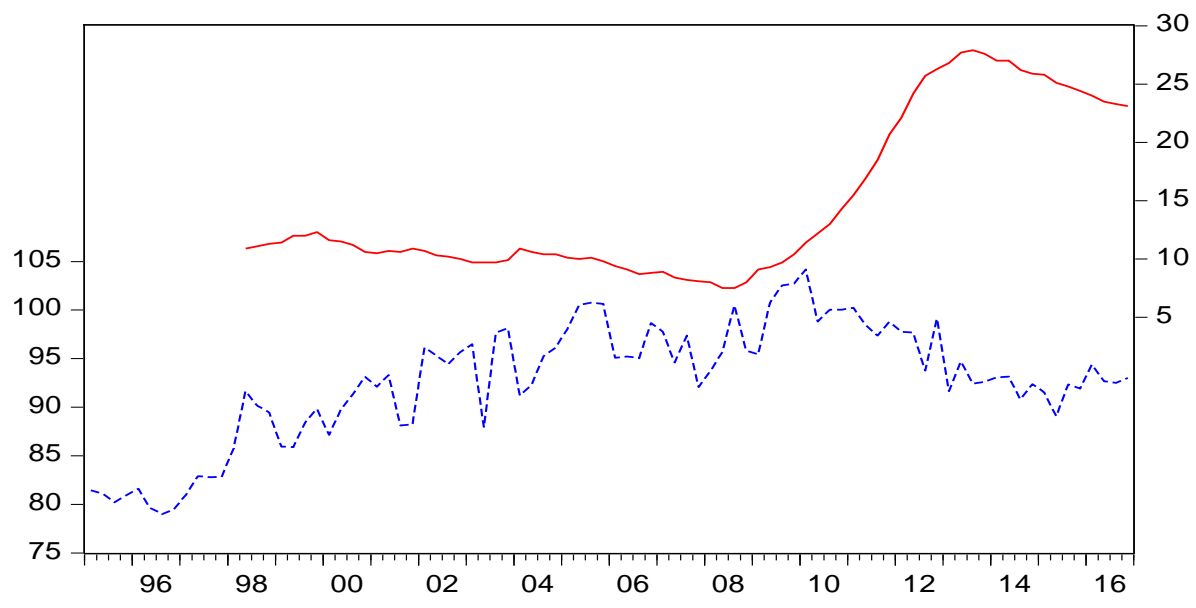

(c) Greece 


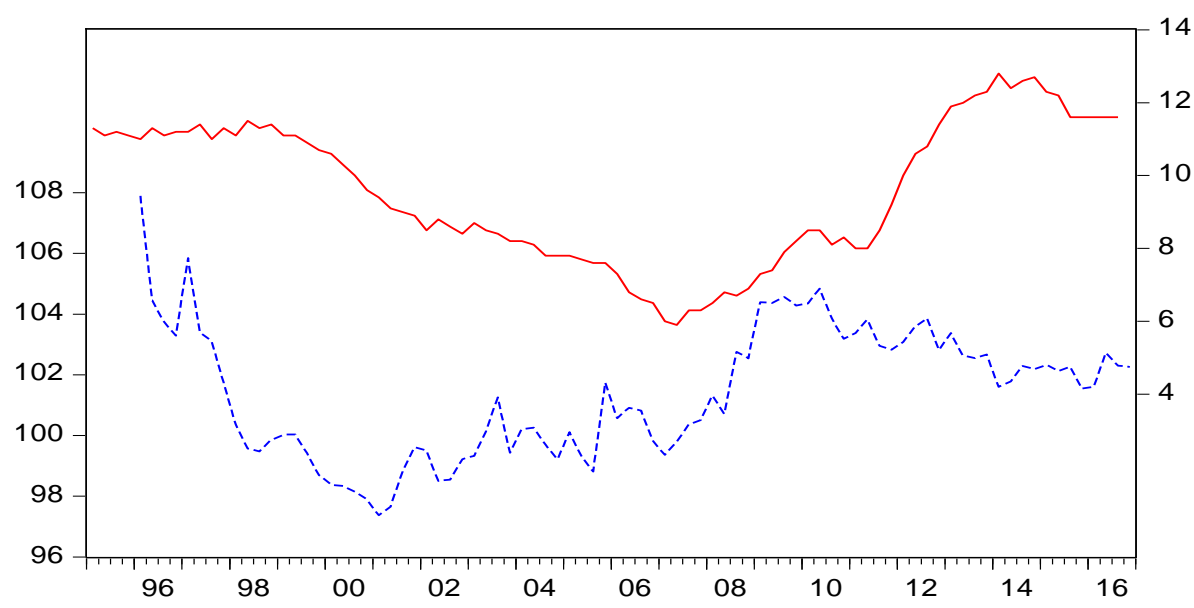

(d) Italy

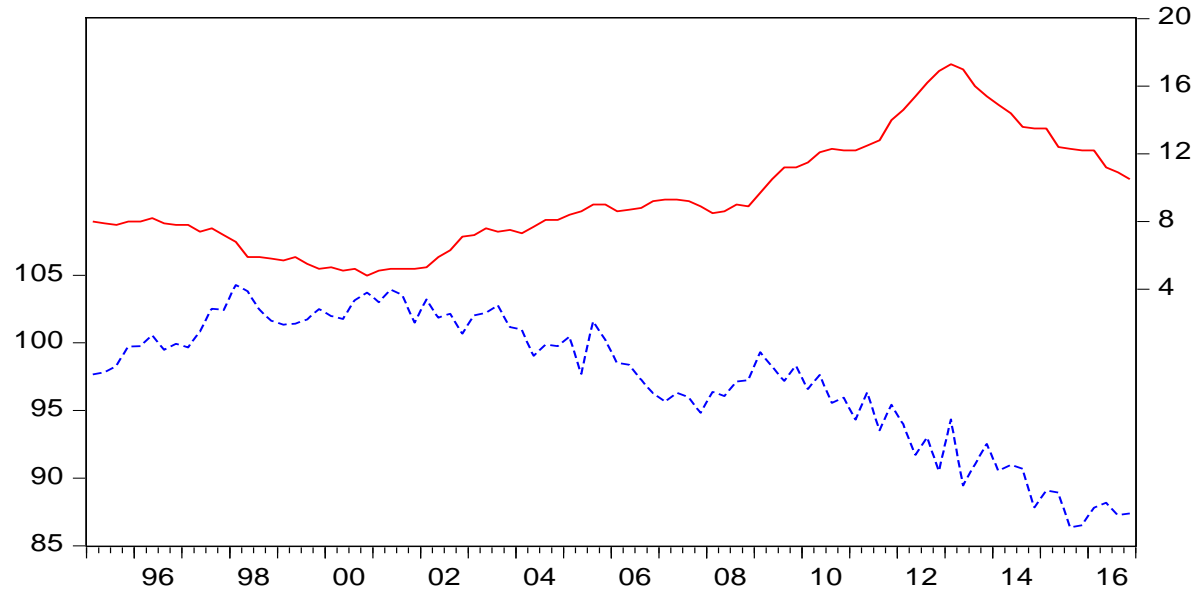

(e) Portugal

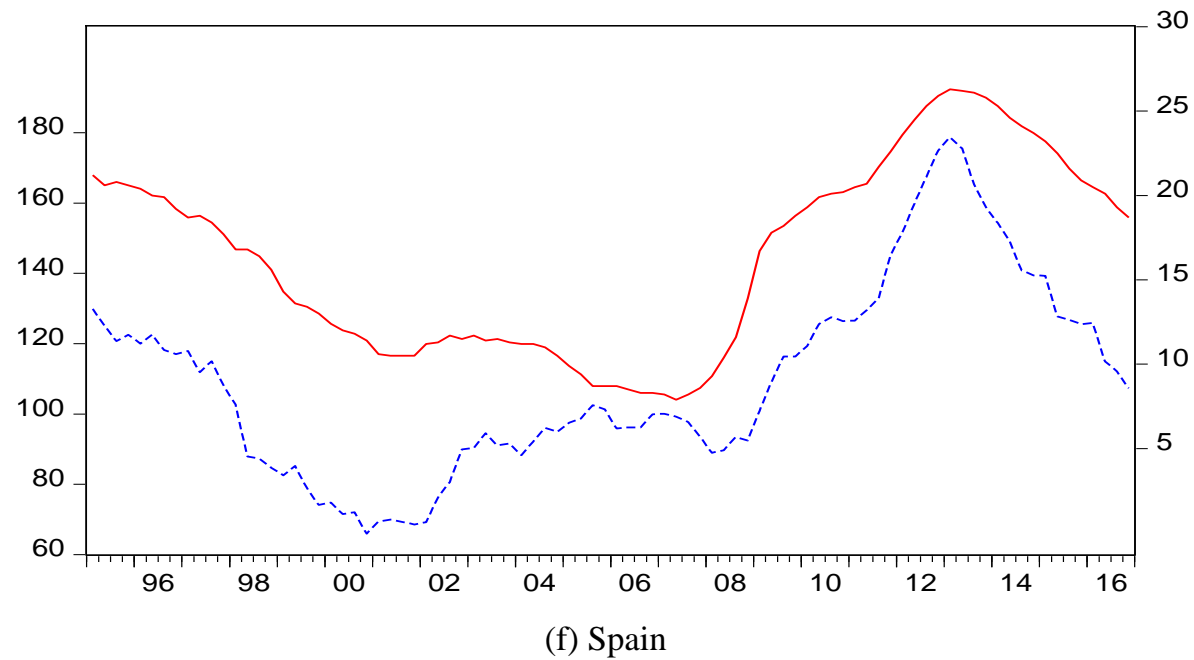

Notes: The real unit labour costs, the dashed curve, are shown on the left axis; index $2005=100$. The unemployment rate, the solid curve, is shown on the right axis; per cent of the labour force. 
It is helpful to consider first the developments in the reference countries, Germany and the Netherlands. Both experienced a surge in unemployment in 2001-2005. The two variables evolve differently after 2009 though; in Germany the unemployment rate kept falling while real unit labour costs were at a more or less constant level, whereas in the Netherlands real unit labour costs surged in 2008-2009 but were afterwards more or less constant, as unemployment increased. Germany carried out a series of labour market reforms that were followed by falling unemployment. Engbom et al. (2015) explain that the measures reduced benefits for the long-term unemployed and tightened the requirements for job search and acceptance, though at the cost of lowering the purchasing power of salaries. Gros (2016) points out that the reduction in wages that was observed in Germany was not the result of purposeful policies but rather the result of rising unemployment. In the Netherlands, the economic slowdown in 2002 weakened the bargaining power of workers as unemployment rose until 2005 with downward pressure on real unit labour costs as the result. In 2003 a law was passed aiming to increase the participation of older employees in the labour market and ease pressures on the pension system, possibly contributing to the rising unemployment for a period of time.

Turning to the GIPS countries there seems to be a negative relationship between real unit labour costs and the unemployment variables in Greece, Italy and Portugal, whereas a positive correlation is present in Spain until 2009. Real unit labour costs in Greece and Italy experienced a clear decline from 2009 onwards, while declines occurred in Portugal from 2000 and in Spain from 2012. The sudden drop in real unit labour costs in Spain is noteworthy. In February 2012, the Spanish government introduced a labour market reform (Royal Decree-Law 3/2012) to reduce supposed rigidities. One of the measures was a reduction of firing costs, while another sought to promote apprenticeship contracts and reduce the cost of hiring.

In Greece, real unit labour costs only started to fall two years after the start of the crisis, perhaps reflecting rigidities in the Greek labour market. Structural reforms started in 2010 with the aim of weakening labour market institutions (Cholezas and Kanellopoulos, 2015). OECD (2013) describes how the Greek government started reforms towards the end of 2011 that were intended to decentralise wage bargaining, reduce employment protection, cut the minimum wage and differentiate it for young employees, increase working time flexibility, and reduce restrictions for hiring and firing workers. This brought labour costs down, and the rise in unemployment slowed from mid-2012. Daude (2016) claims that the fiscal and wage 
adjustments contributed significantly to the recession, while at the same time the lack of reforms to enhance product market competition kept resources in uncompetitive places. As can be seen in Figure 1 for Greece, real unit labour costs stabilised after 2013 and unemployment started to fall.

Portugal undertook in 2011-2015 a series of structural labour market reforms with the aim of reducing long term unemployment and labour market segmentation and increasing market flexibility by changing employment protection legislation, benefits for the unemployed, and bargaining practices, and by freezing the minimum wage to promote wage moderation (OECD, 2017a). The authorities also strengthened the activation framework by increasing the offer of training programmes and by tightening access to unemployment benefits. In addition, Portugal set up subsidies for hiring the unemployed. GDP growth became positive in 2013 which supported the labour market and lowered the unemployment rate. Among other measures that have helped the economic recovery were relaxed barriers to competition in product markets (OECD, 2014). From Figure 1 it can be seen that real unit labour costs have been in decline since 2009 .

In Italy, the Jobs Act, Law 183 of 2014, introduced structural changes such as a new type of permanent contract, a softening of the requirements for firms to monitor their workers, and promotion of the use of temporary contracts. OECD (2015) notes that these measures are meant to boost GDP by 0.6 per cent after five years and 1.2 per cent after ten years, and also to create around 150,000 new jobs in the first five years and another 120,000 jobs in the following five years. However, Fana et al. (2017) find these measures failed to help reduce unemployment, but merely led to a surge in temporary and part time contracts. This is in line with OECD (2017b), which states that the recovery remains weak and productivity continues to decline. However, there was a minor decline in the unemployment rate in 2015, as can be seen from Figure 1.

\section{Methodology and data}

Given the lack of evidence in the literature on how cost competitiveness affect unemployment in the European periphery countries, we aim to shed some light on the issue using SVAR models which take account of interdependences within the economy. We use quarterly data and estimate a SVAR model for each country separately in order to find possible differences between the countries. Given the relatively short sample period available, we estimate a 
parsimonious model with four variables: the unemployment rate, output, the current account balance, and real unit labour costs.

The model specification is derived from previous studies that use VAR models to analyse either imbalances in European countries or the dynamics of costs and unemployment. Among the first group of studies we find Gnimassoun and Mignon (2016), who estimate panel VAR models that contain the output gap, real exchange rates and the current account balance. Comunale (2017) estimates panel VAR models with the same variables and also variables representing conditions in financial markets and the global economy. One study focusing on conditions in the labour market that can be highlighted is Juselius and Ordóñez (2009), who use a cointegrated VAR model for the Spanish economy to analyse the interaction between real wages, unemployment and competitiveness. Bacao et al. (2016) estimate a VAR model that includes unemployment, GDP growth, inflation, interest rates, and the real effective exchange rate for a large number of countries. Earlier studies using VAR models to establish the relationship between labour costs, output performance and unemployment include Balmaseda et al. (2000) for the OECD countries and Dolado and Jimeno (1997) for Spain.

We estimate VAR models using four quarterly variables obtained from the web-based database of Eurostat, where $U$ depicts the unemployment rate divided by 100, LY is the log of real GDP, CA is the current account balance in per cent of GDP divided by 100, and LRULC is the log of the real unit labour costs computed as nominal unit labour costs based on the number of employees and the GDP deflator. The country is distinguished by the following suffixes: Germany (GE), the Netherlands (NL), Greece (GR), Italy (IT), Portugal (PT), and Spain (ES). It follows that for example the variable UGE indicates the unemployment rate for Germany. In most cases the variables were seasonally adjusted by Eurostat, but where seasonally adjusted variables were not available, the X13 multiplicative procedure has been used for seasonal adjustment of the series.

We have used quarterly observations from 1995Q1 to 2016Q4, except in the cases of Greece, for which data on the unemployment rate are available only from 1998Q2 and data on the current account balance only for 2001Q1-2014Q4, and the Netherlands, for which data on real GDP are available only from 1996Q1 and data on the current account balance from 2003Q2.

The ordering of the variables for the SVARs uses Cholesky factorisation and is log real unit labour costs, the current account balance, the unemployment rate, and the log real GDP. This ordering is derived from the assumption that GDP and unemployment react 
contemporaneously to the rest of the variables. Another consequence of the ordering is that the contemporaneous response of unemployment to GDP is restricted to zero. However, we have also examined how the unemployment rate reacts contemporaneously to movements in GDP and the results are qualitatively unchanged (not shown; the results are available on request to the corresponding author).

We use Bayesian econometrics for the truncated sample after 2007Q1. The advantage of Bayesian econometrics over traditional frequentist econometrics is that probability distributions can be obtained for the coefficients of the model if prior information and the likelihood functions obtained from the data are combined to calculate posterior distributions using the Bayes theorem. This means that with our shorter sample, we are potentially able to use a larger set of information than if we base our estimations purely on the sample data. The posterior distribution can be obtained as:

$$
\pi(\delta \mid Y)=\frac{f(Y \mid \delta) \pi(\delta)}{f(Y)}
$$

where $\pi(\delta \mid Y)$ is the posterior distribution conditional to the sample information contained in the data vector $Y, \delta$ is a vector of parameters in the VAR, $f(Y \mid \delta)$ is the likelihood function obtained from the sample, $\pi(\delta)$ is a set of prior information about the parameters and $f(Y)$ is the density function based upon the sample.

Another advantage of Bayesian econometrics according to Sims (1988) is that inference is not affected by unit roots in the data, so the presence of $\mathrm{I}(1)$ variables should not be a problem in this case.

In this paper we make use of the normal-Wishart prior distribution, which is based on the standard Minnesota prior by Litterman (1986). Litterman (1986) posits that since macro variables are often I(1) processes, the autoregressive parameter in the set of priors is assumed to be equal to 1 , and 0 for the remaining parameters. It is also assumed that $\delta$ is normally distributed.

The normal-Wishart distribution relaxes the assumption that the residual covariance matrix is known. The variance can be expressed as $\sigma_{a_{i j}}^{2}=\left(1 / \sigma_{j}^{2}\right)\left(\lambda_{1} / l^{\lambda_{3}}\right)$, where $l$ is the coefficient lag, $\lambda_{1}$ is the own lag variance, or overall tightness, and $\lambda_{3}$ is a scaling constant which accounts for the speed of convergence to 0 for the coefficients of lags greater than 1 . Following the literature we choose $\lambda_{1}=0.1$ and $\lambda_{3}=1$. 


\section{Results}

\subsection{Results for the full sample}

The SVARs are based on VARs estimated with two lags, a length that is chosen using the Akaike Information Criterion. Figure 2 shows the impulse response functions of real GDP and unemployment to a one-unit innovation in real unit labour costs for the reference countries Germany and the Netherlands and the GIPS countries, Greece, Italy, Portugal and Spain. ${ }^{4}$ To facilitate comparison across the countries, we consider innovations or shocks of one unit, rather than one standard deviation as commonly used.

\footnotetext{
${ }^{4}$ The full set of impulse response functions is shown in Figure A.1 in Appendix.
} 
Figure 2: Impulse responses to shock in unit labour costs

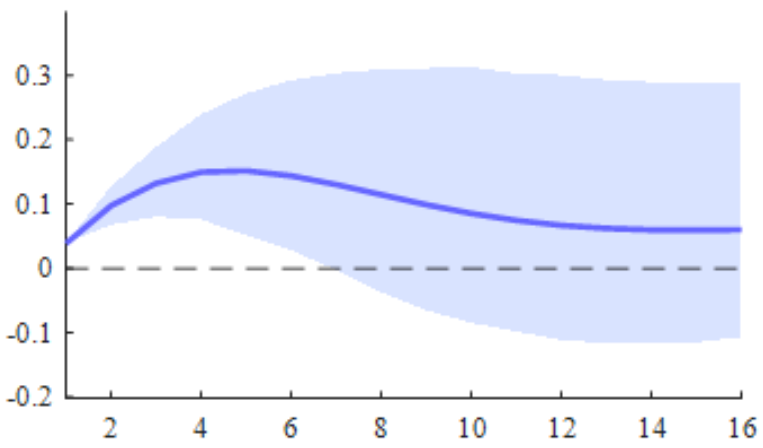

(a1) Germany: response of unemployment (UGE)

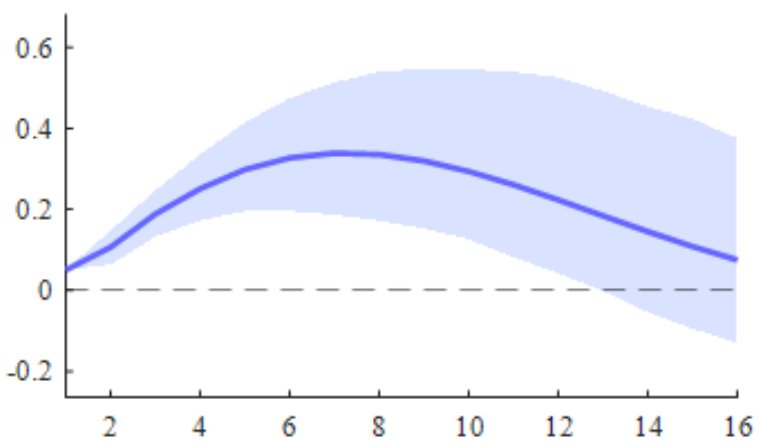

(b1) Netherlands: response of unemployment (UNL)

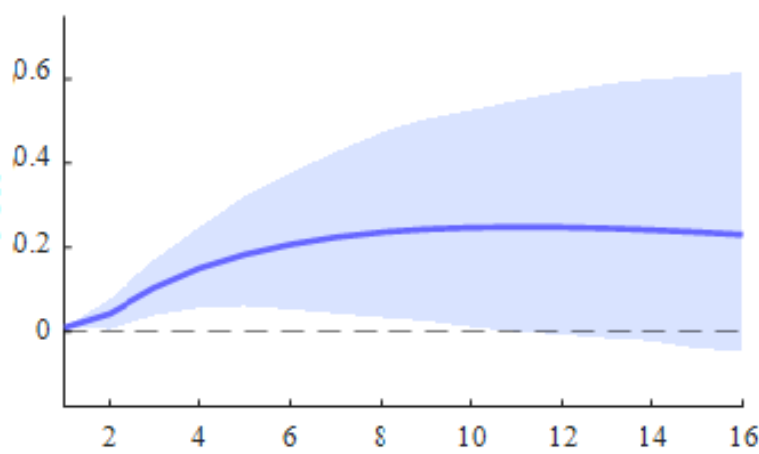

(c1) Greece: response of unemployment (UGR)

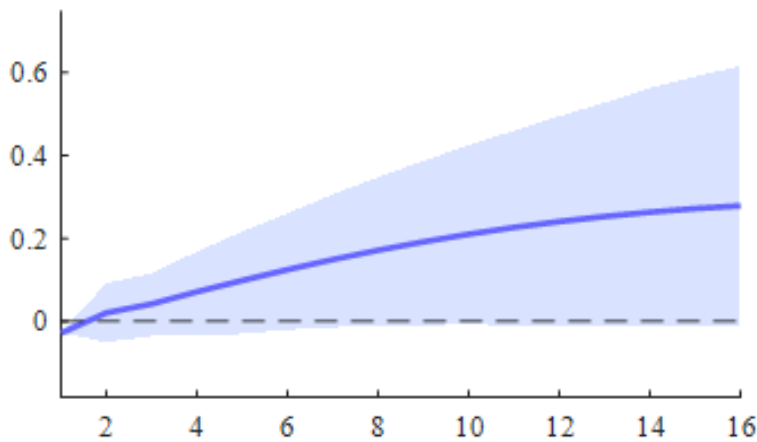

(d1) Italy: response of unemployment (UIT)

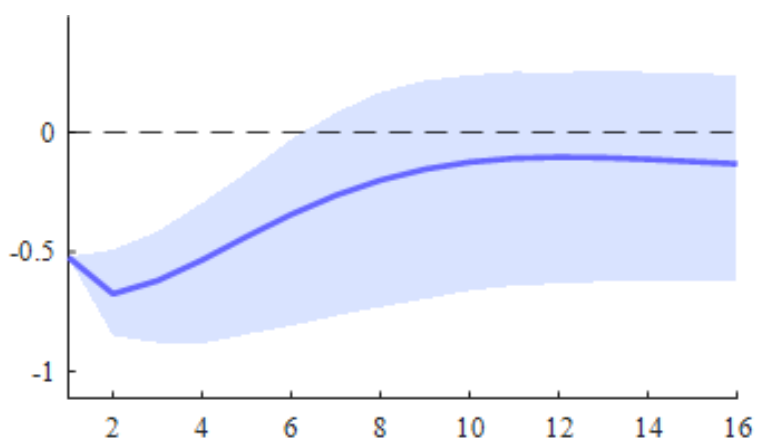

(a2) Germany: response of GDP (LYGE)

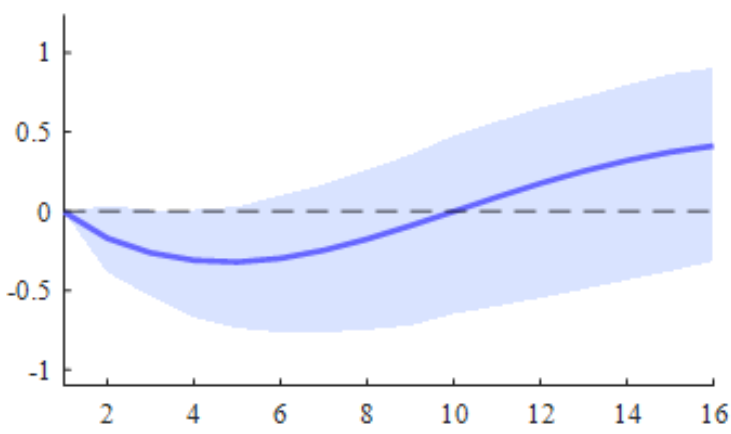

(b2) Netherlands: response of GDP (LYNL)

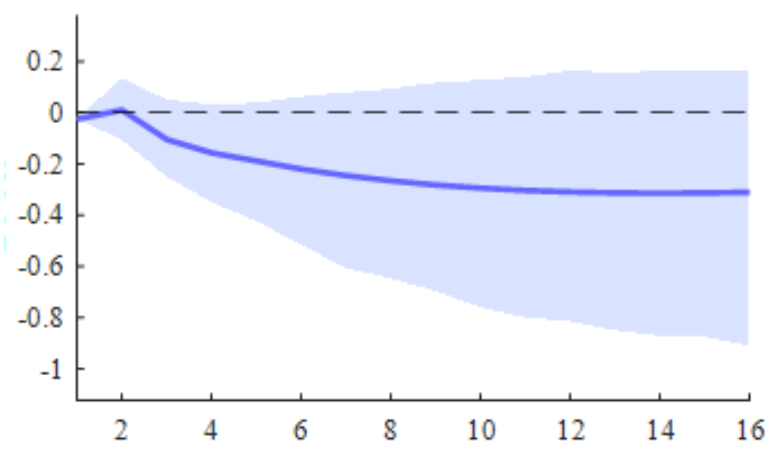

(c2) Greece: response of GDP (LYGR)

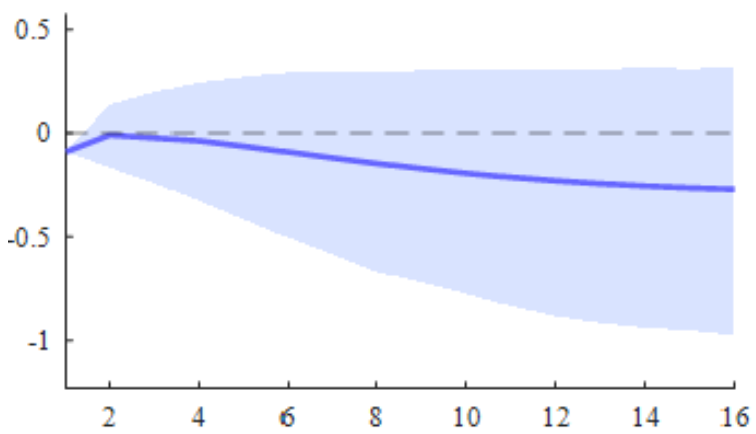

(d2) Italy: response of GDP (LYIT) 


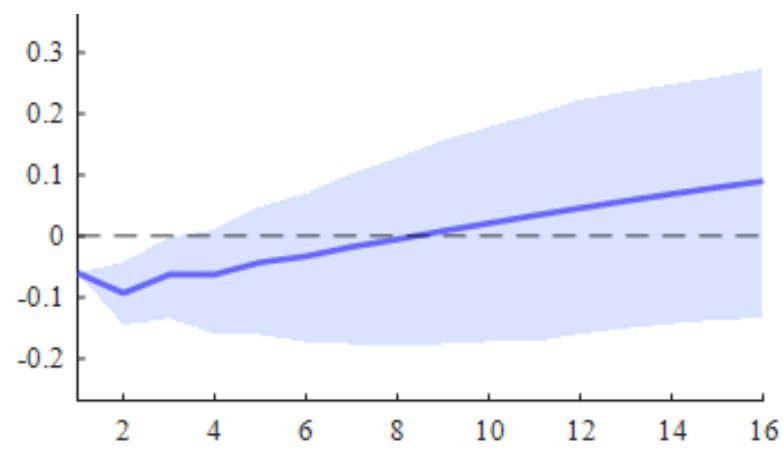

(e1) Portugal: response of unemployment (UPT)

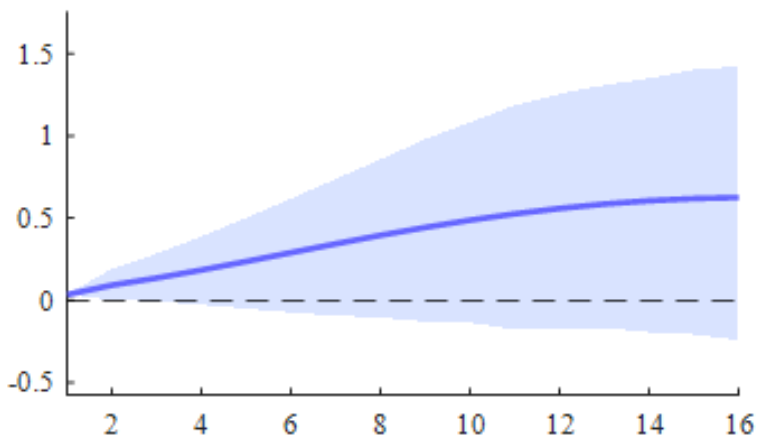

(f1) Spain: response of unemployment (UES)

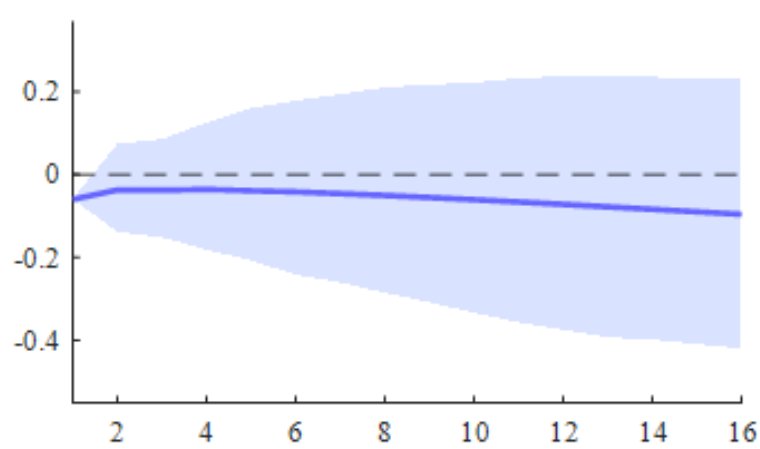

(e2) Portugal: response of GDP (LYPT)

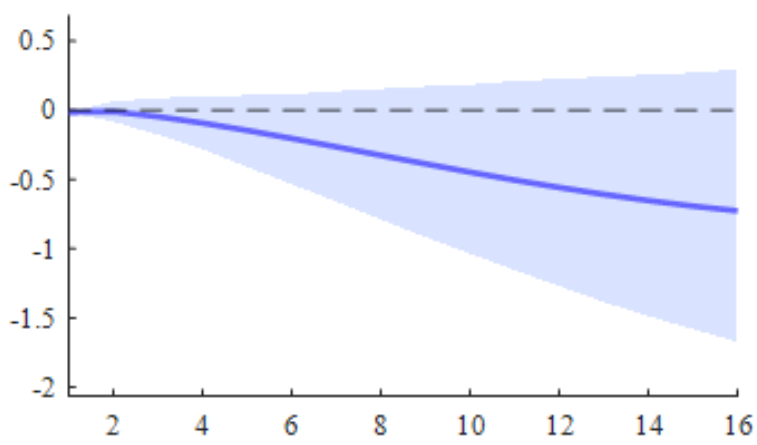

(f2) Spain: response of GDP (LYES)

Note: The graphs show the impulse responses to a one-unit innovation in real unit labour costs (LRULC). The solid curve indicates the median, the shadowed areas the $95 \%$ confidence interval.

We show first the results for the reference countries. Focusing on the reaction of unemployment and real GDP to shocks in real unit labour costs in Germany, we observe that such shocks have a positive and significant effect on unemployment, and a negative and significant effect on real GDP. This is what would be expected from an aggregate supply shock affecting production costs. Furthermore, the current account shows a negative and significant reaction. For the Netherlands, unemployment reacts positively and significantly to a competitiveness shock, but the reaction of real GDP is barely significant. A difference between Germany and the Netherlands is that real unit labour costs seem to react negatively after a real GDP shock in the Netherlands, but the effect is not significant for Germany.

With the impulse response functions for the GIPS countries, the first feature to notice is that competitiveness shocks typically do not produce statistically or economically significant effects in either real GDP or unemployment. Reductions in real unit labour costs do not seem to boost output or reduce unemployment in ways that are economically or statistically significant. These results for the GIPS countries are clearly different from those for Germany and the Netherlands. 
If follows from Figure A.1 in Appendix that a positive current account shock, amounting to capital outflows, has a negative and significant effect on economic growth and a negative one on unemployment for Greece and Portugal. This result illustrates the role of capital inflows in the economic performance of Greece and Portugal during the great moderation prior to the crisis. For Spain in contrast, we observe that improvements in the current account balance seem to have had a beneficial effect on unemployment and economic growth. In the case of Italy, we do not find a significant effect of the current account on neither unemployment nor GDP.

\subsection{Results for the post-crisis sample}

The results in Subsection 4.1 are based on estimations on a sample of 15 years, depending on the country, including the pre-crisis period. We continue by estimating VAR models for the period 2007Q1-2016Q4 to ensure that the results are not driven by the dynamics of the precrisis boom but retain their relevance during the crisis period. Figure 3 reports the posterior impulse responses for the unemployment rate and for real GDP to a one-unit shock in unit labour costs, found from the Bayesian SVARs estimated on the post-2007 sample. 
Figure 3: Posterior impulse responses to shock in unit labour costs, model for post-2007Q1
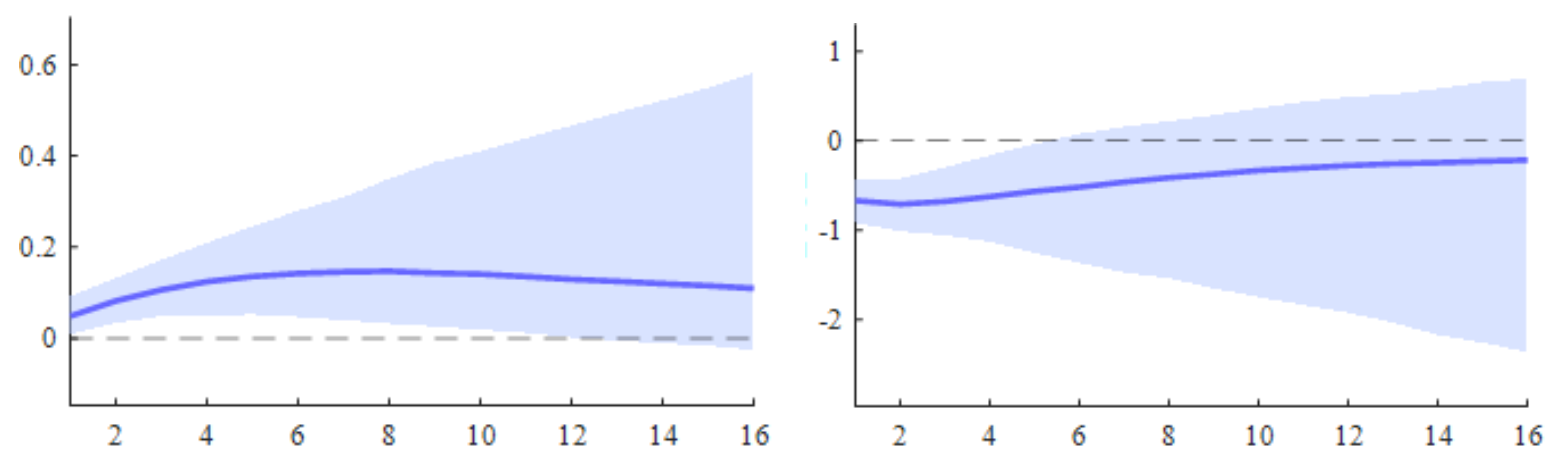

(a1) Germany: response of unemployment (UGE)

(a2) Germany: response of GDP (LYGE)
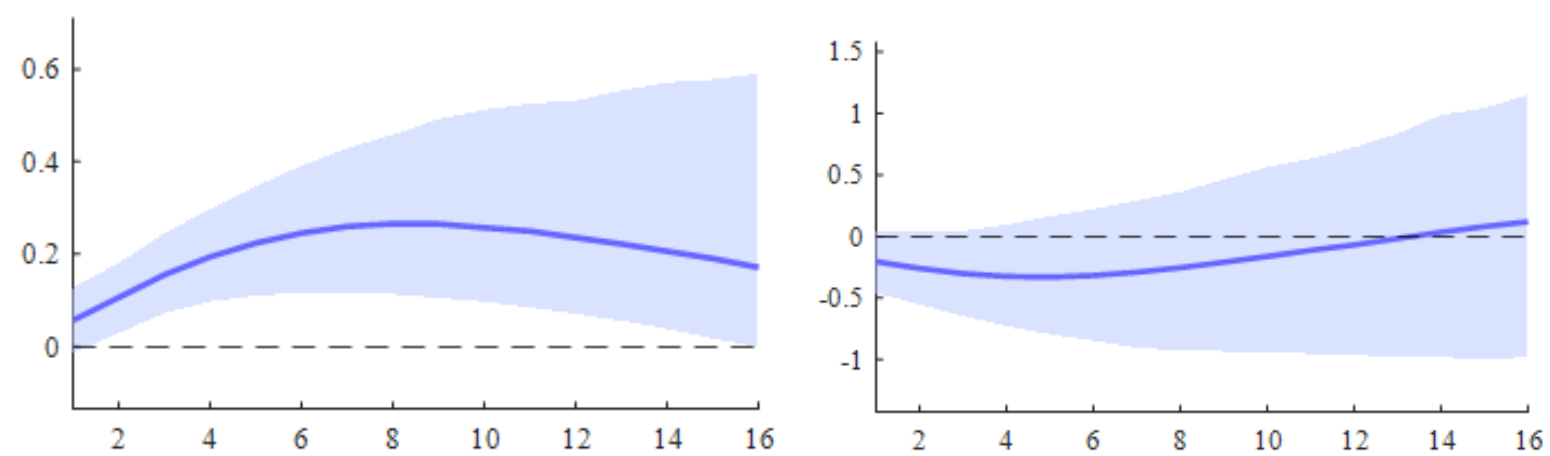

(b1) Netherlands: response of unemployment (UNL)

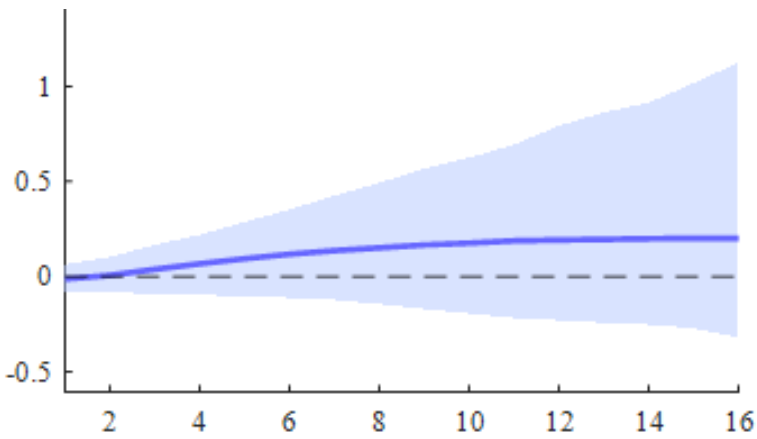

(b2) Netherlands: response of GDP (LYNL)

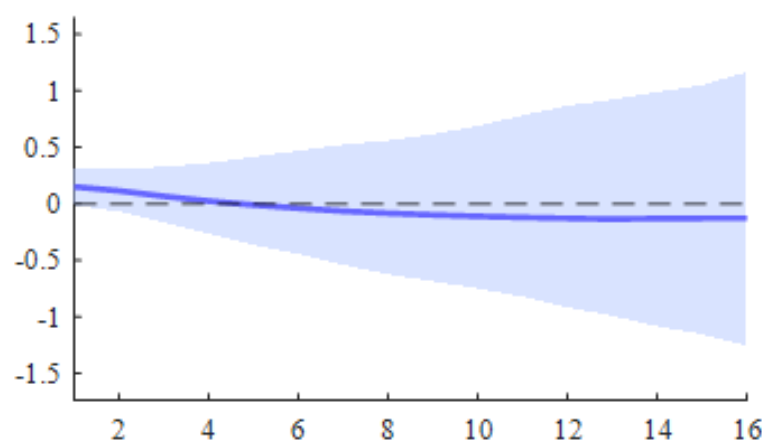

(c1) Greece: response of unemployment (UGR)

(c2) Greece: response of GDP (LYGR)
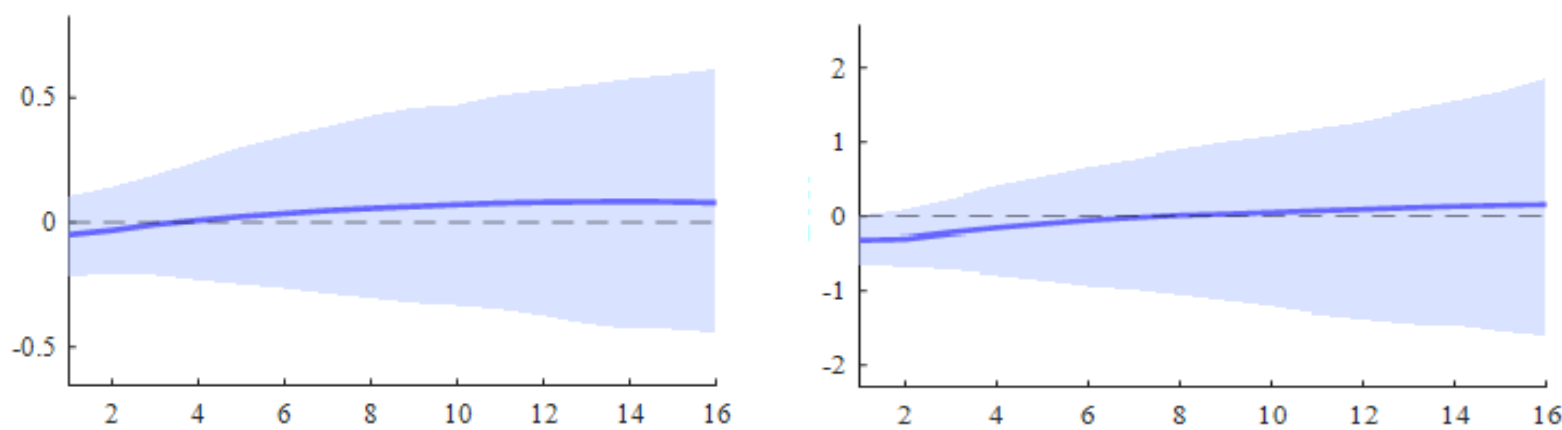

(d1) Italy: response of unemployment (UIT)

(d2) Italy: response of GDP (LYIT) 


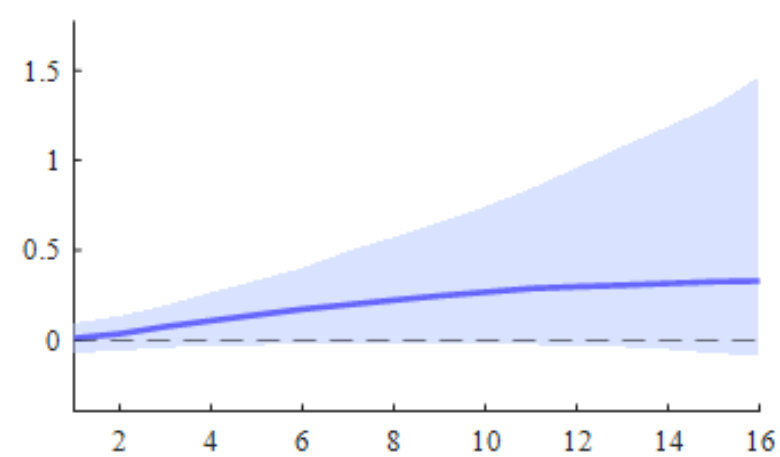

(e1) Portugal response of unemployment (UPT)

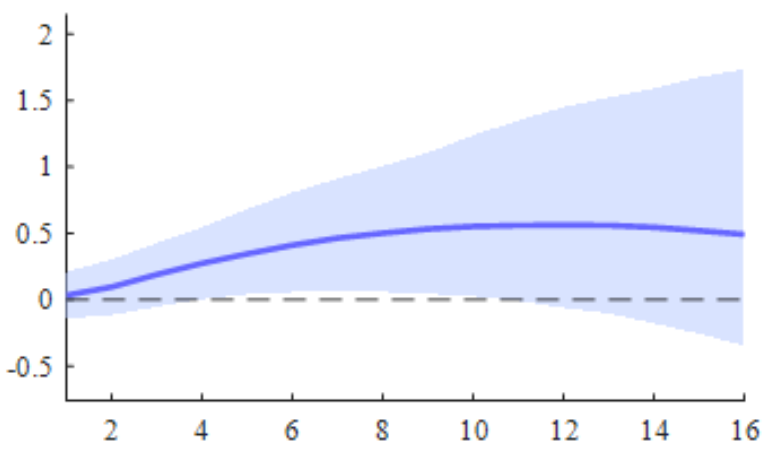

(f1) Spain: response of unemployment (UES)

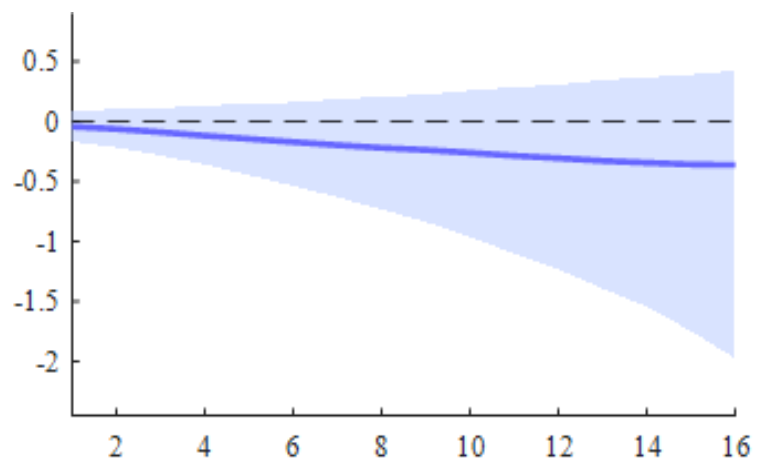

(e2) Portugal: response of GDP (LYPT)

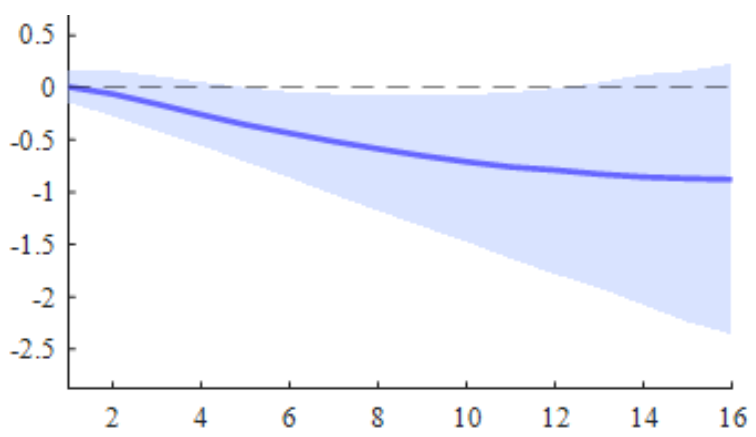

(f2) Spain: response of GDP (LYES)

Note: The graphs show the impulse responses to a one-unit innovation in real unit labour costs (LRULC). The solid curve indicates the median, the shadowed area the $95 \%$ credible set.

The results reveal that the posterior response shifts enough for the credible sets not to contain the 0-line only for Germany and the Netherlands, suggesting that higher unit labour costs affects the unemployment rate negatively for both countries and also GDP for Germany. For the GIPS countries the results are quite similar to those obtained using the full sample; a shock in real unity labour costs fail to shift the posterior impulse response functions much in nearly all cases. The only exception is Spain, for which the credible sets for both the unemployment rate and GDP do not contain the 0-line between the fourth and the tenth quarters after the shock. ${ }^{5}$

In conclusion, the results are broadly similar whether the VAR is estimated using frequentist econometrics on the full sample or using Bayesian econometrics on the shorter post-crisis sample. The main finding is that lower real unit labour costs appear to have positive and

\footnotetext{
${ }^{5}$ The median maximum effect for the unemployment rate is indeed the highest of any country after about 3-4 years, with an impact of about 0.5 per cent after a shock of 1 per cent two years earlier.
} 
statistically significant effects on unemployment and output for the northern European reference countries, while the corresponding effects are typically smaller and imprecisely estimated for the southern European countries most affected by the great recession.

The heterogeneity between the two groups clearly eclipses the heterogeneity within the groups. The only exception is the results for Spain when the sample is limited to the period after 2007Q1, where we find that changes in real unit labour costs have a substantial but delayed and imprecisely estimated effect on unemployment. The results for Greece, Italy and Portugal are clear and point to changes in real unit labour costs having no or only limited effects.

\section{Final comments}

The GIPS economies in southern Europe have been under economic strain during the great recession following the 2007-2008 global financial crisis. The output dynamics has been subdued and unemployment rates elevated. This raises the question whether the countries can soften the downturn and reduce unemployment rates using policy measures that target cost competitiveness. The GIPS countries have indeed all introduced labour market reforms and other measures to improve cost competitiveness.

This paper estimates quarterly SVAR models and presents impulse responses showing how shocks to real unit labour costs affect output and unemployment. The analyses are carried out for the four GIPS countries individually and the results are compared with those of the reference countries, Germany and the Netherlands. The data are from 1995Q1 to 2016Q4, but additional estimations using Bayesian methods are run on the sample from 2007Q1 to 2016Q4 to ensure that the results also apply to the period after the start of the crisis.

The results are very similar for the models estimated on the two different samples. A negative innovation in real unit labour costs, implying improved cost competitiveness, is followed by increased output and lower unemployment for up to two years in the reference core countries Germany and the Netherlands. The effects of lower real unit labour costs in the four periphery countries generally trace the same pattern as in the reference countries, but the effects are smaller and less precisely determined.

The results overall corroborate the view that changes in real unit labour costs are not a key driving force behind the dynamics of output and unemployment in the GIPS countries; instead 
changes in real unit labour costs are in large part the endogenous response of other factors changing in the economy, including GDP and unemployment; cf. also the discussion in Section 1. The results may thus cast some doubt on the effectiveness of structural reforms that seek to lower employment costs in the crisis countries. Daude (2016) and OECD (2017b) argue that the impact of the structural reforms passed in Greece and Italy since the start of the crisis has been limited, at least in the short term.

The heterogeneity across different countries and country groups suggests that measures to improve cost competitiveness cannot be seen as a one size fits all response applicable to all countries. Specifically, the effects of policy measures designed to improve cost competitiveness are quite uncertain for the crisis countries in southern Europe. This casts doubts on how effective such measures are as a means for boosting output performance and reducing unemployment rates in these countries. 


\section{References}

Bacao, P., A. Portugal Duarte and D. Machado (2016): Exchange rates, the competitiveness of nations and unemployment, GEMF Working Papers, 2016-14, Faculty of Economics, University of Coimbra.

Balmaseda, M., J. J. Dolado and J. D. López-Salido (2000): The dynamic effects of shocks to labour markets: evidence from OECD countries, Oxford Economic Papers, vol. 52, pp. $3-23$.

Blanchard, O. and J. Wolfers (2000): The role of shocks and institutions in the rise of European unemployment: the aggregate evidence, Economic Journal, vol. 110, pp. 133.

Blanchard, O. and P. Portugal (2017): Boom, slump, sudden stops, recovery and policy options. Portugal and the euro, Portuguese Economic Journal, vol. 16, pp. 149-168.

Caporale, G. M. and L. A. Gil-Alana (2014): Youth unemployment in Europe: persistence and macroeconomic determinants, Comparative Economic Studies, vol. 56, pp. 581-591.

Cholezas, I. and N. C. Kanellopoulos (2015): Labour market reforms in Greece and the wage curve, Economics Letters, vol. 136, pp. 19-21.

Cirillo, V. and D. Guarascio (2015): Jobs and competitiveness in a polarised Europe, Intereconomics, vol. 21, pp. 156-160.

Comunale, M. (2017): A panel VAR analysis of macro-financial imbalances in the EU, ECB Working Paper Series, no. 2026, European Central Bank.

Daude, C. (2016): Structural reforms to boost inclusive growth in Greece, OECD Economics Department, Working Papers, no. 1298.

Dolado, J. J. and J. F. Jimeno (1997): The causes of Spanish unemployment: a structural VAR approach, European Economic Review, vol. 41, pp. 1281-1307.

Dustmann, C. and B. Fitzenberger (2014): From sick man of Europe to economic superstar: Germany's resurgent economy, Journal of Economic Perspectives, vol. 28, pp. 167188. 
EC (2017): Macroeconomic imbalance procedure, European Commission, https://ec.europa.eu/info/business-economy-euro/economic-and-fiscal-policy-coordination/eueconomic-governance-monitoring-prevention-correction/macroeconomic-imbalance-procedure_en.

Engbom, N., E. Detragiache and F. Raei (2015): The German labor market reforms and postunemployment earnings, IMF Working Paper, no. WP/15/162.

Fana, M., D. Guarascio and V. Cirillo (2017): Labour market reforms in Italy: evaluating the effects of the Jobs Act, Economia Politica, vol. 34, pp. 211-232.

Felipe, J. and U. Kumar (2014): Unit labour costs in the Eurozone: the competitiveness debate again, Review of Keynesian Economics, vol. 2, pp. 490-507.

Gabrisch, H. and K. Staehr (2015). The Euro Plus Pact. Competitiveness and external capital flows in the EU Countries, Journal of Common Market Studies, vol. 53, pp. 558-576.

Galí, J. and Monacelli, T. (2016): Understanding the gains from wage flexibility: the exchange rate connection, American Economic Review, vol. 106, pp. 3829-3868.

Gnimassoun, B. and V. Mignon (2016): How do macroeconomic imbalances interact? Evidence from a panel VAR analysis, Macroeconomic Dynamics, vol. 20, pp. 17171741 .

Gros, D. (2016): Adjustment within the euro area: is it all about competitiveness? CEPS Special Report, no. 127, Centre for European Policy Studies.

Guerrieri, P. and P. Esposito (2012). Intra-European imbalances, adjustment, and growth in the Eurozone, Oxford Review of Economic Policy, vol. 28, pp. 532-550.

Hall, P. A. (2012). The economics and politics of the euro crisis, German Politics, vol. 21, pp. $355-371$.

Juselius, K. and J. Ordóñez (2009): Balassa-Samuelson and Wage, Price and Unemployment Dynamics in the Spanish Transition to EMU Membership, Economics: The OpenAccess, Open-Assessment E-Journal, vol. 3, article 4.

Litterman, R. (1986): Forecasting with Bayesian Vector Autoregressions - Five years of experience, Journal of Business and Economic Statistics, vol. 2, pp. 497-498.

OECD (2013): OECD Economic Surveys. Greece, OECD Publishing. 
OECD (2014): Portugal: Deepening Structural Reform to Support Growth and Competitiveness, OECD Publishing.

OECD (2015): Italy: Structural Reforms: Impact on Growth and Employment, OECD Publishing.

OECD (2017a): Labour Market Reforms in Portugal 2011-2015, OECD Publishing.

OECD (2017b): OECD economic surveys: Italy 2017, OECD Publishing.

Ordóñez, J., H. Sala and J. I. Silva (2015): Real unit labour costs in Eurozone countries: drivers and clusters, IZA Journal of European Labor Studies, vol. 4, pp. 1-19.

Schmitt-Grohé, S. and M. Uribe (2016): Downward nominal wage rigidity, currency pegs, and involuntary unemployment, Journal of Political Economy, vol. 124, pp. 14661514.

Sims, C. A. (1988): Bayesian skepticism on unit root econometrics, Journal of Economic Dynamics and Control, vol. 12, pp. 463-474.

Sinn, H. W. (2014): Austerity, growth and inflation: remarks on the eurozone's unresolved competitiveness problem, World Economy, vol. 37, pp. 1-13.

Staehr, K. and R. Vermeulen (forthcoming): heterogeneous effects of competitiveness shocks on macroeconomic performance across euro area countries, World Economy.

Stockhammer, E. and D. P. Sotiropoulos (2014): Rebalancing the euro area: the costs of internal devaluation, Review of Political Economy, vol. 26, pp. 210-233.

Storm, S. and C. W. M. Naastepad (2014): Europe's Hunger Games: income distribution, cost competitiveness and crisis, Cambridge Journal of Economics, vol. 39, pp. 959-986.

Storm, S. and C. W. M. Naastepad (2015): Crisis and recovery in the German economy: the real lessons, Structural Change and Economic Dynamics, vol. 32, pp. 11-24.

Wyplosz, C. (2013): The Eurozone crisis and the competitiveness legend, Asian Economic Papers, vol. 12, pp. 63-81.

Zemanek, H. (2010): Competitiveness within the euro area: the problem that still needs to be solved, Economic Affairs, vol. 30, pp. 42-27. 
Appendix

Figure A.1: Impulse response functions (with $95 \%$ confidence intervals) 

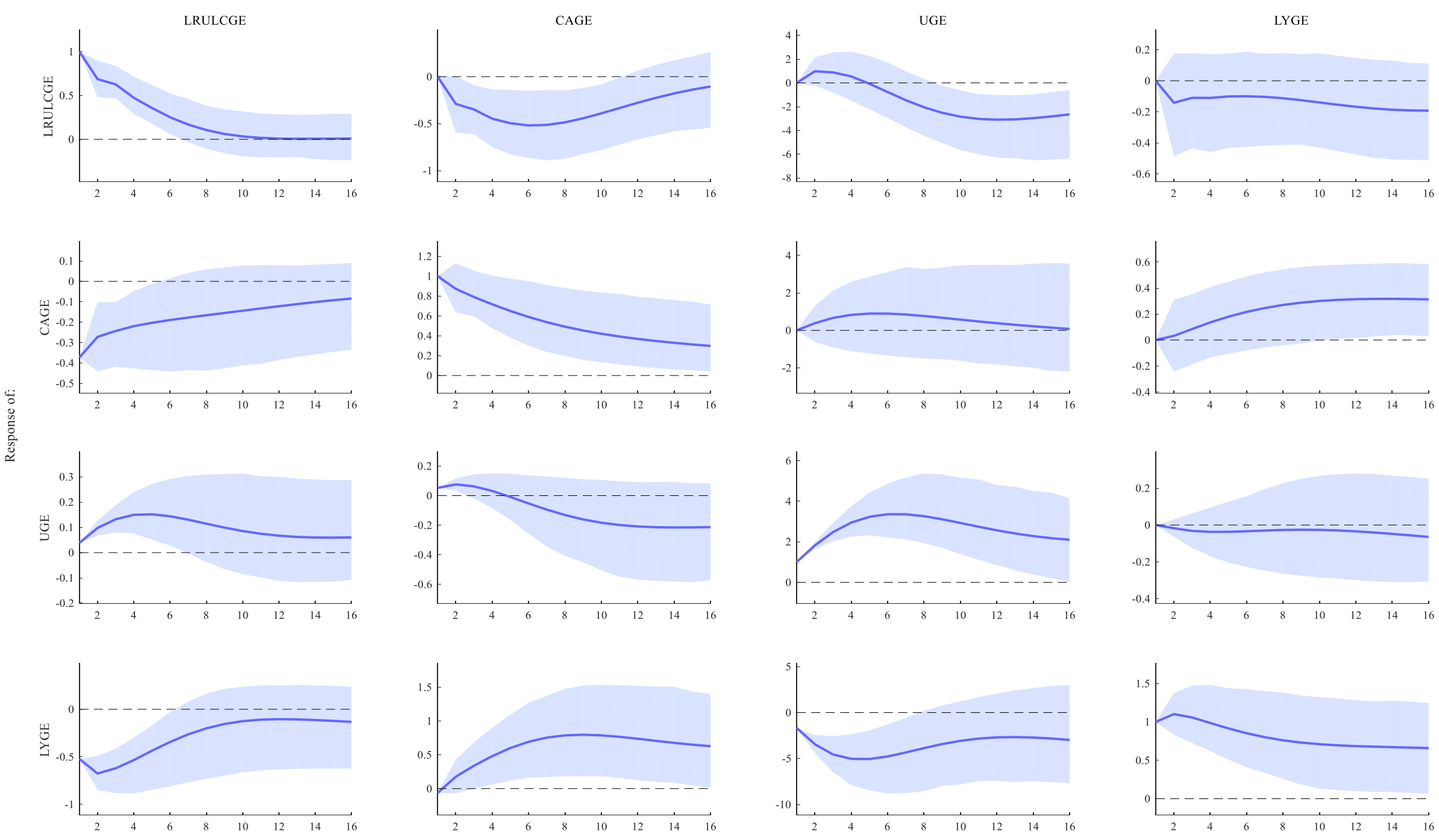

(a) Germany 

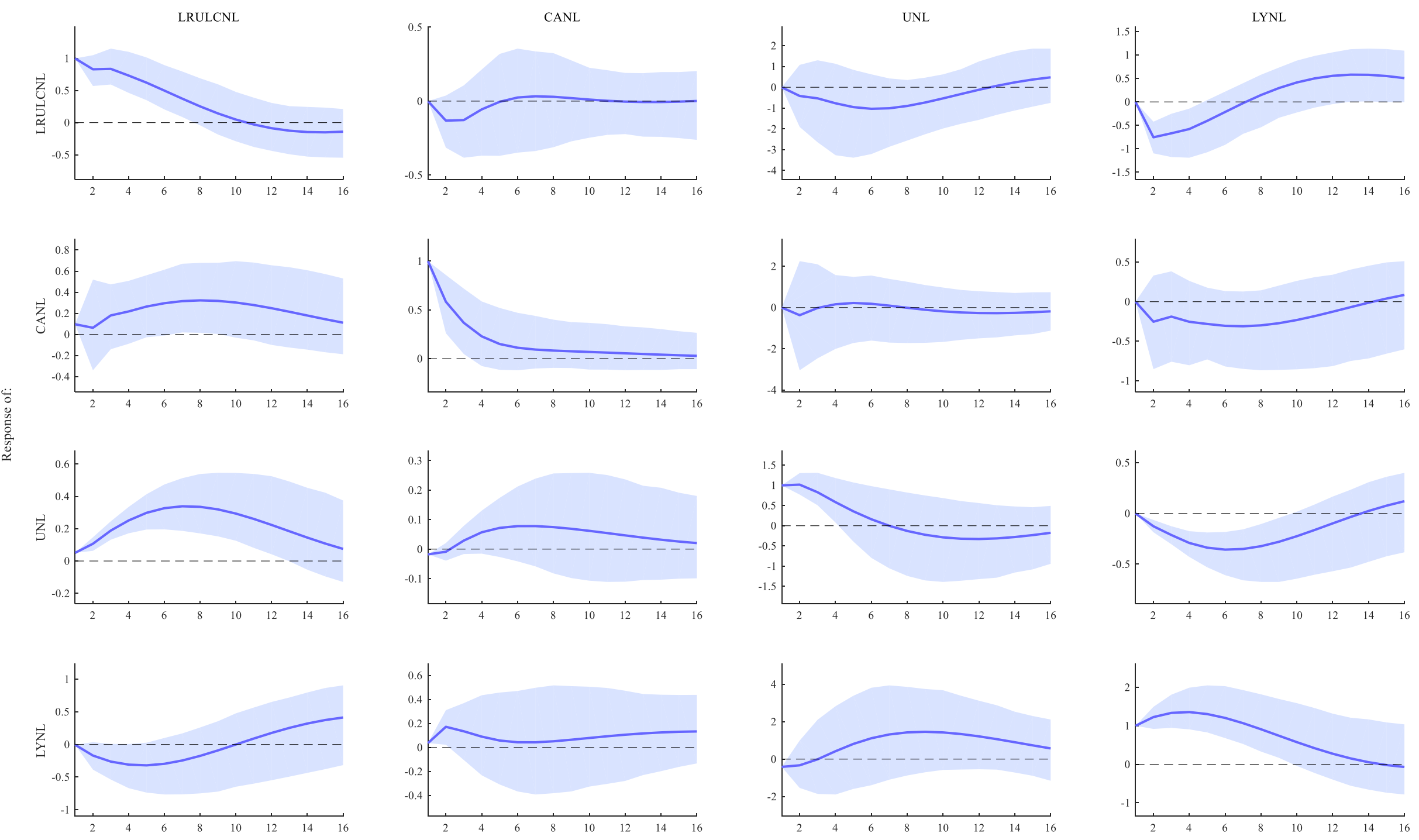

(b) Netherlands 

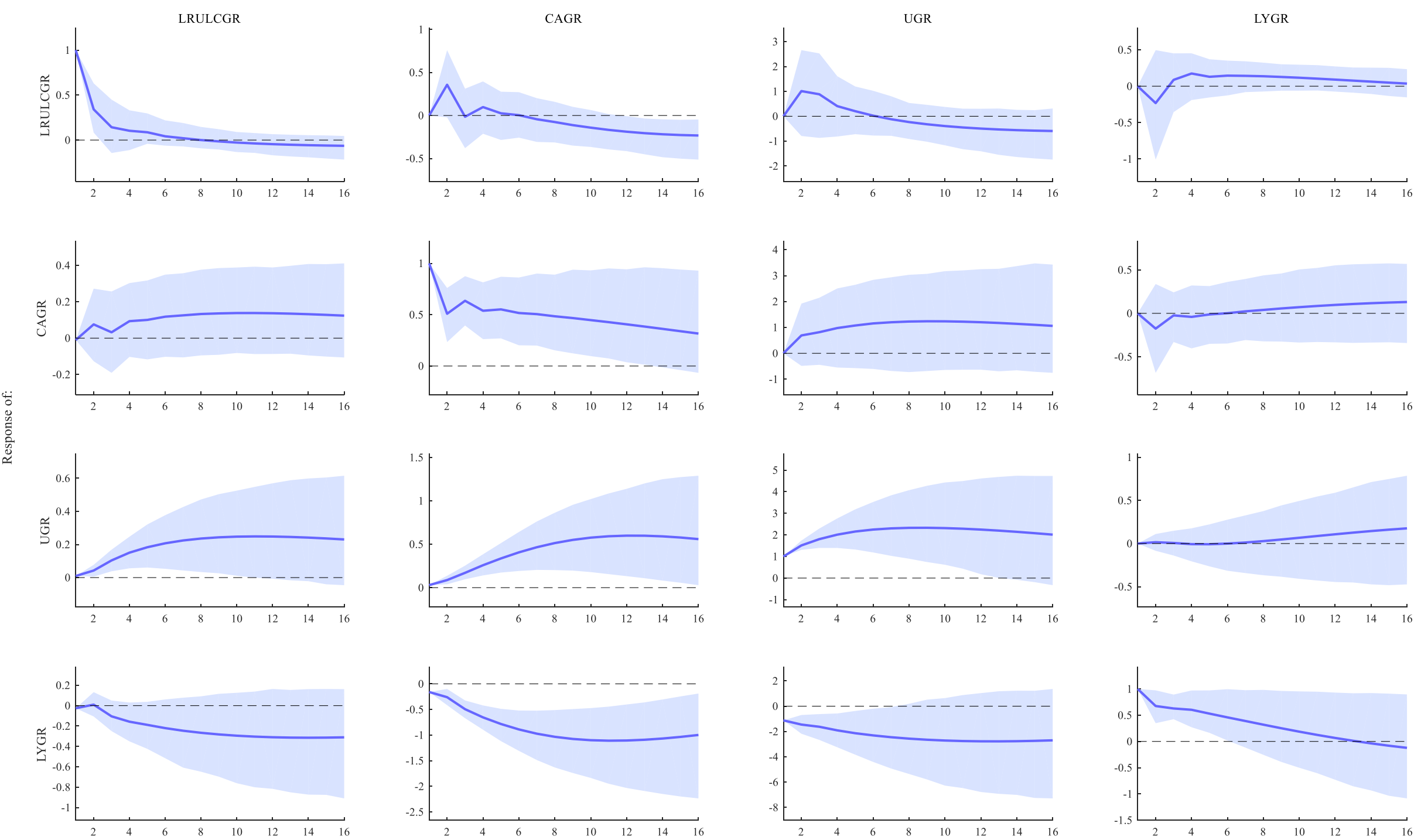

(c) Greece 

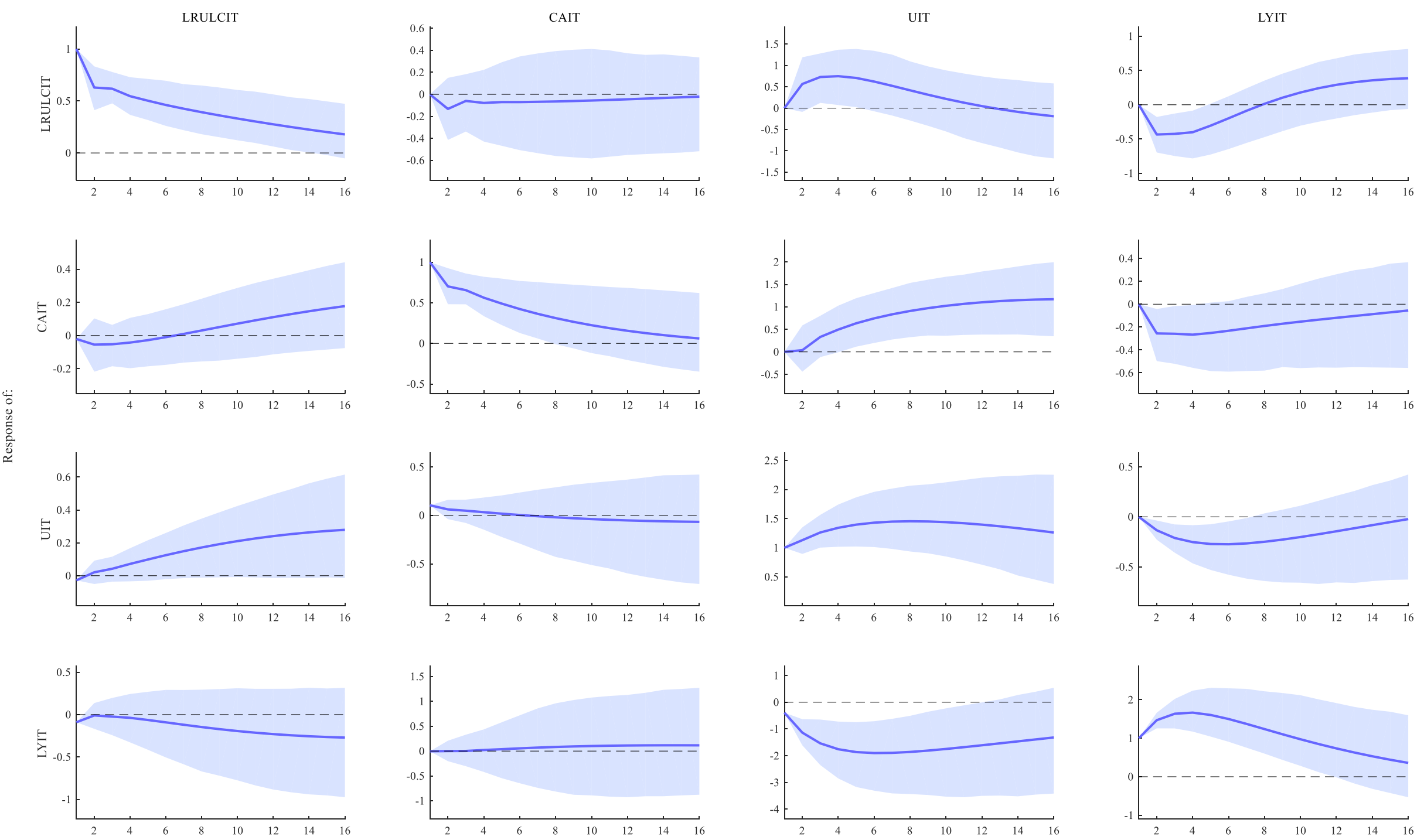

(d) Italy 

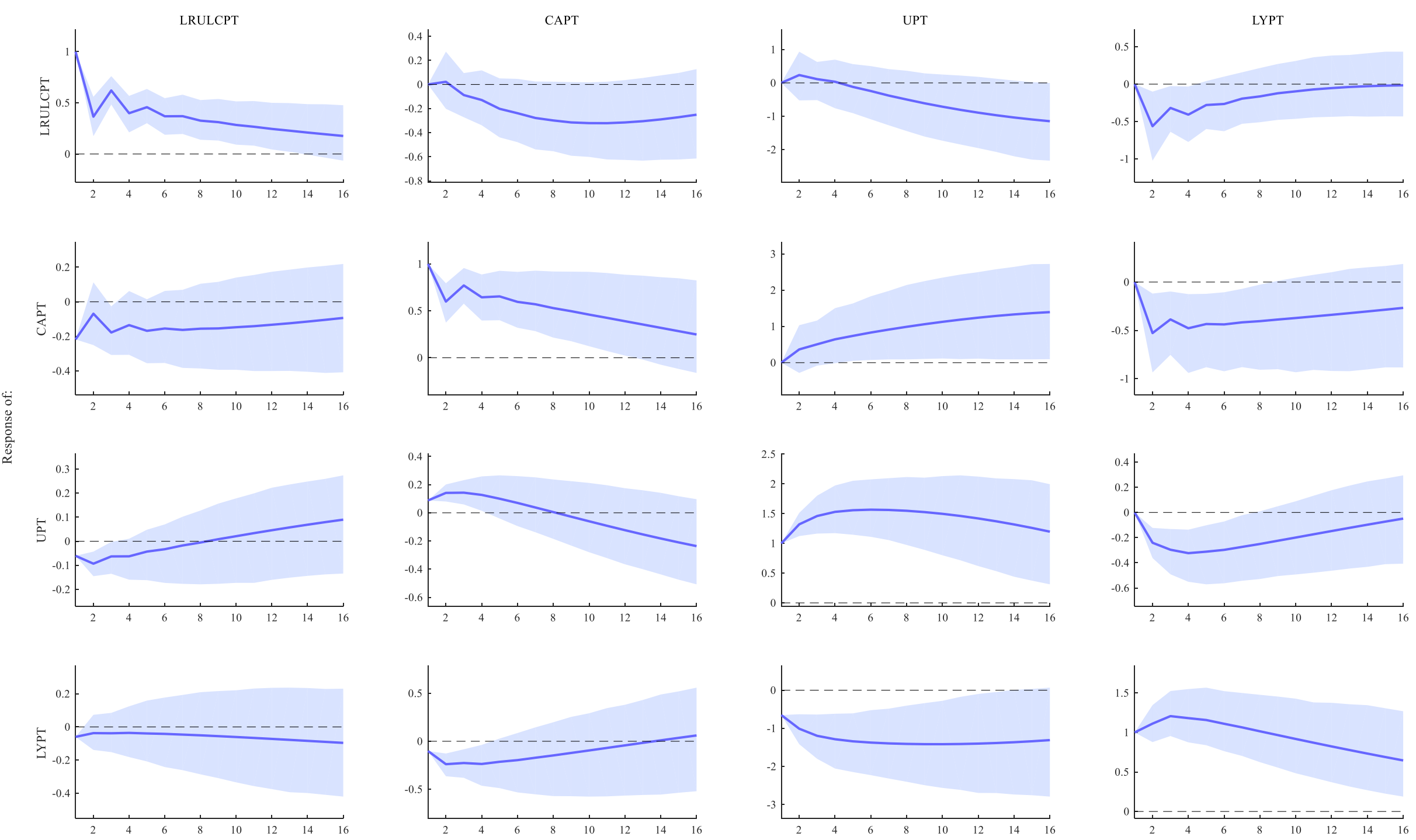

(e) Portugal 

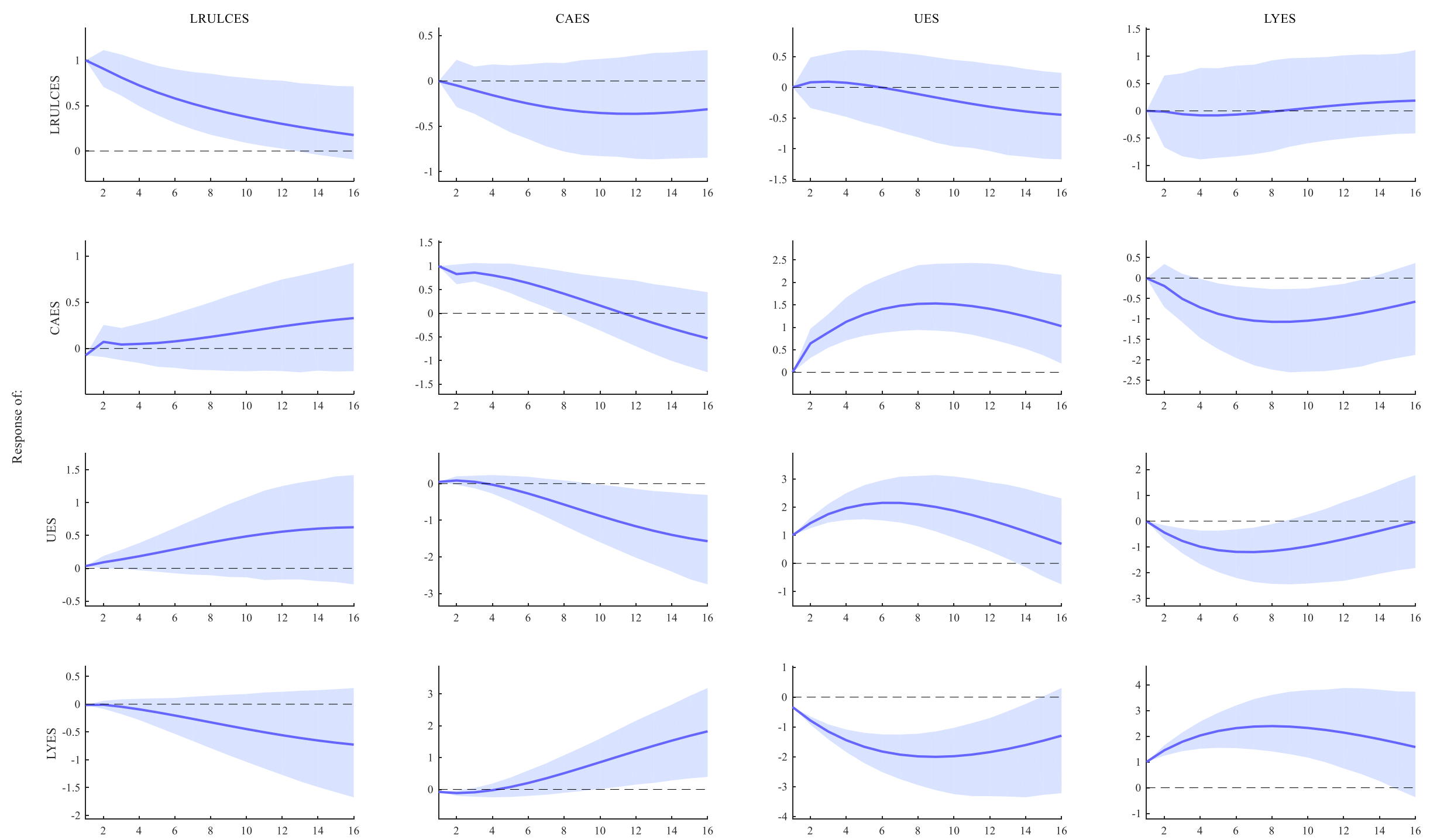

(f) Spain 